Postgraduate Bosowa University Publishing (PBUP)
Indonesian Journal of Business and Management
JOURNAL
https://postgraduate.universitasbosowa.ac.id/index.php/jbm

\title{
IMPLEMENTASI BAURAN PEMASARAN TERHADAP MINAT PEMBELIAN RUMAH (STUDI KASUS PADA PT KALIMASADA DI BERAU)
}

\author{
The Implementation of Marketing Mix toward the Interest in Buying a House \\ (A Case Study at PT. Kalimasada Berau)
}

\author{
Fajriani $^{1}$, Hasanuddin Remmang ${ }^{2}$, Chahyono $^{2}$ \\ ${ }^{1}$ Magister Manajemen Universitas Bosowa Makassar \\ ${ }^{2}$ Program Studi Manajemen Program Pascasarjana Universitas Bosowa \\ Email: fajrianiraudah@gmail.com
}

Diterima: 12 Agustus 2020 /Disetujui: 07 Desember 2020

\begin{abstract}
ABSTRAK
Penelitian tersebut dianalisis dengan menggunakan analisis regresi linear berganda dengan menggunakan data primer yang diperoleh dari jawaban responden sebanyak 100 orang pembeli dan user perumahan kalimasada. Penelitian ini bertujuan untuk mengetahui implementasi bauran pemasaran secara simultan berpengaruh signifikan terhadap minat beli konsumen di perumahan kalimasada Berau. Berdasarkan hasil uji penelitian ini, bauran pemasaran dengan variabel orang, promosi dan tampilan fisik berpengaruh secara signifikan terhadap minat pembelian di perumahan kalimasada. Untuk variabel yang lain tidak berpengaruh signifikan terhadap minat beli konsumen pada perumahan Kalimasada.
\end{abstract}

Kata Kunci: Bauran Pemasaran, Minat Pembelian, Perumahan

\section{ABSTRACT}

This study was analyzed using multiple linear regression analysis, using primary data obtained from respondents' answers as many as 100 buyers and users of Kalimasada housing. This study aims to determine whether the implementation of the marketing mix simultaneously has a significant effect on consumers' interest in buying a house in Kalimasada residence, Berau. Based on the testing results of this study, the marketing mix with the variables of people, promotion, and physical appearance has a significant effect on the interest in buying a house in Kalimasada residence. Meanwhile, other variables do not have a significant effect on consumer interest in buying a house in Kalimasada residence.

Keywords: Marketing Mix, Interest in Buying, Consumer, Residence

\section{PENDAHULUAN}

Perumahan di Indonesia merupakan suatu kebutuhan dasar manusia dan mempunyai fungsi yang strategis dalam perannya sebagai pusat pendidikan keluarga, persemaian budaya, dan peningkatan kualitas generasi akan datang. Terwujudnya kesejahteraan rakyat dan sumber daya manusia yang berkualitas dapat ditandai dengan meningkatnya kualitas kehidupan yang layak dan bermartabat melalui kebutuhan papannya (Arsyad, 2003).

Jenis strategi pemasaran yang akan digunakan oleh perusahaan properti tersebut, dalam penelitian ini yaitu strategi bauran pemasaran yang terdiri dari 7 elemen. Strategi bauran pemasaran yaitu strategi yang dapat meliputi produk, harga, promosi, tempat, orang, bukti fisik dan proses menurut (Philiph Kotler, 2000). Bauran pemasaran dan kualitas layanan berpengaruh positif dan signifikan secara parsial maupun simultan terhadap komitmen konsumen (Wally, at.al, 2020)

Bauran pemasaran terdapat variabel yang saling mendukung satu dengan yang lainnya, yang kemudian oleh perusahaan digabungkan untuk memperoleh tanggapan yang diinginkan didalam pasar sasaran. Untuk mengatasi persaingan pasar bisnis yang semakin ketat dan agar perusahaan dapat mempertahankan kelangsungan hidupnya, maka perusahaan harus teliti dalam menganalisis kesempatan yang dapat dimanfaatkan dengan melihatkan kekuatan dan juga kelemahan yang 
dimiliki oleh perusahaan. Dan juga mempersiapkan diri twehadap menghadapi ancaman-ancaman yang terjadi dalam bisnis (Lupiyoadi, 2001; Lestari, 2011).

PT Kalimasada adalah salah satu pengembang atau developer penyedia perumahan di kalimantan timur yaitu di kota berau. Tentu akan sangat memprihatinkan sistem bauran pemasaran dari konsep pemasaran perumahan yang sedang dikembangkan saat ini. Dalam menghadapi persaingan pasar dalam waktu satu tahun lebih PT Kalimasada mampu menjual sebanyak 150 unit rumah. Hal ini merupakan hal yang menarik untuk menganalisis implementasi bauran pemasaran yang digunakan oleh perusahaan tersebut. Berdasarkan latar belakang masalah diatas penulis memilih judul tesis yaitu Implementasi Bauran Pemasaran Terhadap Minat beli Rumah Studi Kasus Pada PT Kalimasada di Berau.

\section{METODE PENELITIAN}

Metode penelitian kuantitatif yang dapat diartikan sebagai sebuah metode penelitian yang berlandaskan pada filsafat positivisme, digunakan untuk meneliti populasi atau sampel tertentu. Teknik pengambilan sampel pada umumnya dilakukan secara random, pengumpulan data menggunakan instrumen penelitian, analisis data bersifat kuantitatif atau statistik dengan tujuan untuk menguji hipotesis yang telah ditetapkan (Sugiyono, 2012).

Populasi ialah wilayah generalisasi yang terdiri dari objek dan subjek yang mempunyai kualitas dan karakteristik tertentu yang diterapkan oleh penulis untuk dipelajari dan ditarik kesimpulannya (Sugiono, 2007). Adapun yang menjadi popuasi dalam penelitian ini adalah beberapa konsumen yang telah membeli unit rumah pada perumahan PT Kalimasada pada 1 tahun terakhir yaitu tahun 2019 dan beberapa warga atau calon konsumen disekitar lokasi penelitian yang berjumlah 134 orang.

Analisis data merupakan sebuah proses pengolahan, penyajian, interpretasi dan analisis data yang diperoleh dari lapangan, dengan tujuan agar data yang disajikan memiliki makna, sehingga pembaca dapat mengetahui hasil penelitian yang dilakukan (Martono, 2011: 143). Dalam menentukan analisis data, diperlukan data yang akurat dan bisa dipercaya yang nantinya dapat dipergunakan dalam penelitian yang akan dilakukan oleh penulis. Analisis data merupakan proses penyederhanaan data kedalam bentuk yang lebih mudah dibaca, dipahami dan diinterpretasikan.

Analisis data yang dilakukan dengan menggunakan bantuan dari program SPSS Versi 21 sebagai alat untuk meregresikan model yang telah dirumuskan. Teknik analisis data yang digunakan dalam penelitian ini adalah statistika deskriptif, yaitu dengan tabulasi data dari hasil pengumpulan data responden untuk menentukan jumlah dan persentase responden. Pengujian statistik deskripsi untuk variable penelitian bauran pemasaran dan minat beli pada perumahan PT Kalimasada.

\section{HASIL DAN PEMBAHASAN}

\subsection{Uji Validitas dan Reliabilitas}

Dari olah data yang menggunakan SPSS, maka diperoleh nilai dari uji validitas yang menunjukan perbedaan disetiap indikator-indikator atau instrument pengukuran dalam penelitian ini. >Berdasarkan tabel diketahui bahwa semua indikator memilki rhirung > rtabel 0,195 dengan responden sebanyak 100 orang. Jadi dapat disimpulkan variabel penelitian dinyatakan valid.

Hasil pengujian reliabilitas data memperlihatkan nilai koefisien reliabilitas sebesar 0.878 dengan jumlah aitem sebanyak 28 .

Tabel 1. Reliabilitas Data

\begin{tabular}{|c|c|}
\hline Cronbach's Alpha & $\mathrm{N}$ of Items \\
\hline .878 & 28 \\
\hline
\end{tabular}
dengan indikator masing-masing, maka seluruh indikator dinyatakan reliabel. Pada tabel diatas menunjukkan bahwa Cronbach's Alpha lebih besar dari 0,60.

\subsection{Uji F (Simultan)}

Berdasarkan tabel di atas, diketahui nilai uji $\mathrm{F}$ hitung sebesar 8,509 dengan tingkat signifikansi $0,000<0,05$. Dengan nilai $\mathrm{F}$ tabel sebesar 2,04, dengan kesimpulan Fhitung > Ftabel, maka $\mathrm{H}_{0}$ ditolak dan $\mathrm{H}_{1}$ diterima. Dapat disimpulkan bahwa semua variabel independen yaitu produk, harga, tempat, promosi, orang/SDM, bukti fisik dan proses dalam penelitian ini secara bersamaan berpengaruh terhadap variabel dependen yaitu minat beli konsumen pada perumahan kalimasada.

\subsection{Uji t (Parsial)}

Uji t yaitu suatu uji untuk mengetahui signifikansi pengaruh variabel bebas secara parsial atau individual terhadap variabel terikat. Hasil uji t pada penelitian ini dapat dilihat pada tabel berikut ini:

Tabel 2. Uji t

\begin{tabular}{|c|c|c|c|c|c|}
\hline \multirow{2}{*}{ Model } & \multicolumn{2}{|c|}{$\begin{array}{c}\text { Unstandardized } \\
\text { Coefficients }\end{array}$} & \multirow{2}{*}{$\begin{array}{c}\begin{array}{c}\text { Standardized } \\
\text { Coefficients }\end{array} \\
\text { Beta }\end{array}$} & \multirow{2}{*}{$\mathbf{t}$} & \multirow{2}{*}{ Sig. } \\
\hline & B & $\begin{array}{l}\text { Std. } \\
\text { Error }\end{array}$ & & & \\
\hline (Constant) & 10.589 & 2.724 & & 3.888 & .000 \\
\hline Produk & 0.429 & 0.227 & 0.196 & 1.889 & 0.062 \\
\hline Harga & -0.282 & 0.197 & -0.129 & -1.429 & 0.157 \\
\hline Tempat & 0.053 & 0.18 & 0.027 & 0.295 & 0.769 \\
\hline Promosi & 0.431 & 0.153 & 0.289 & 2.813 & 0.006 \\
\hline Orang & 0.338 & 0.163 & 0.192 & 2.074 & 0.041 \\
\hline $\begin{array}{l}\text { Bukti } \\
\text { Fisik }\end{array}$ & 0.474 & 0.212 & 0.238 & 2.233 & 0.028 \\
\hline Proses & -0.106 & 0.181 & -0.054 & -0.588 & 0.558 \\
\hline
\end{tabular}

Sumber : Hasil Olah Data SPSS 21

\subsection{Uji Determinasi (R2)}

Untuk hasil uji persamaan regresi 2 (dua) yang digunakan untuk melihat pengaruh bauran pemasaran yang meliputi produk, harga, tempat, promosi, orang/SDM, bukti fisik dan proses terhadap minat beli konsumen, dapat dilihat dari tabel dibawah ini: 
Tabel 3. Uji R2

\begin{tabular}{c|c|c|c|c}
\hline Model & $\mathbf{R}$ & $\begin{array}{c}\text { R } \\
\text { Square }\end{array}$ & $\begin{array}{c}\text { Adjusted R } \\
\text { Square }\end{array}$ & $\begin{array}{c}\text { Std. Error of the } \\
\text { Estimate }\end{array}$ \\
\hline 1 & $.627^{\mathrm{a}}$ & .393 & .347 & 1.955 \\
\hline \multicolumn{3}{l}{ Sumber: Hasil Olah data SPSS 21} \\
\end{tabular}

Dari tabel diatas output dari Adjusted R Square adalah sebesar 0,347 , hal ini menyatakan bahwa bauran pemasaran dengan variabel produk, harga, tempat, promosi, orang/SDM, bukti fisik dan proses terhadap minat beli konsumen pada perumahan kalimasada adalah sebesar $34,7 \%$ sementara sisanya $(100 \%-34,7 \%=$ $65,3 \%$ ) dijelaskan oleh variabel lainnya yang tidak diteliti dalam penelitian ini.

Implementasi Bauran Pemasaran Variabel Produk Terhadap Minat Beli Konsumen di Perumahan Kalimasada

Dari hasil pengujian hipotesis diketahui bahwa variabel produk tidak mempunyai pengaruh yang signifikan terhadap minat beli konsumen pada perumahan kalimasada. Dapat disimpulkan bahwa perlu adanya pembaruan dalam desain perumahan kalimasada dan bisa menambah dan membangun tipe perumahan yang lain untuk meningkatkan minat beli konsumen.

Implementasi Bauran Pemasaran Variabel Harga Terhadap Minat Beli Konsumen di Perumahan Kalimasada

Dari hasil pengujian hipotesis diketahui bahwa variabel harga tidak berpengaruh signifikan terhadap minat beli konsumen pada perumahan kalimasada. Dapat disimpulkan bahwa perlu adanya penawaran harga yang beragam yang bisa menjadi daya tarik dalam minat beli pada perumahan kalimasada. Hal ini tentu membawa dampak yang baik jika dijalankan dengan menggunakan strategi yang benar.

Implementasi Bauran Pemasaran Variabel Tempat Terhadap Minat Beli Konsumen di Perumahan Kalimasada

Dari hasil pengujian hipotesis diketahui bahwa variabel tempat tidak berpengaruh signifikan terhadap minat beli konsumen pada perumahan kalimasada. Dapat disimpulkan bahwa sejauh ini tata letak lokasi perumahan kalimasada masih dianggap kurang sesuai ataupun belum strategis, dengan fasilitas yang dianggap belum memenuhi kemauan konsumen. Meskipun akses jalur tempat tersebut sudah ramai oleh kendaraan umum, namun belum memberi pengaruh terhadap minat beli konsumen.

Implementasi Bauran Pemasaran Variabel Promosi Terhadap Minat Beli Konsumen di Perumahan Kalimasada

Dari hasil pengujian hipotesis diketahui bahwa variabel promosi berpengaruh signifikan terhadap minat beli konsumen pada perumahan kalimasada. Dapat disimpulkan bahwa promosi yang dilakukan oleh perusahaan kalimasada seperti pengiklanan di media sosial dalam pemasaran memberikan dampak yang sangat baik. Dan juga kegiatan sponsor yang dilakukan oleh pihak perusahaan di masyarakat dinilai membantu meningkatkan niali promosi.

Implementasi Bauran Pemasaran Variabel Orang/SDM Terhadap Minat Beli Konsumen di Perumahan Kalimasada

Dari hasil pengujian hipotesis diketahui bahwa variabel orang/SD berpengaruh signifikan terhadap minat beli konsumen pada perumahan kalimasada. Dapat disimpulkan bahwa SDM atau karyawan pada bidang pelayanan di perumahan kalimasada direspon baik oleh responden, dengan indikator sikap profesional karyawan yang dinilai positif.

Implementasi Bauran Pemasaran Variabel Bukti Fisik Terhadap Minat Beli Konsumen di Perumahan Kalimasada

Dari hasil pengujian hipotesis diketahui bahwa variabel bukti fisik berpengaruh signifikan terhadap minat beli konsumen pada perumahan kalimasada. Dapat disimpulkan bahwa pada pernyataan tata letak perumahan yang rapi dan teratur memberi dampak yang positif di mata konsumen maupun user, namun belum memberikan dampak yang tinggi terhadap penjualan rumah.

Implementasi Bauran Pemasaran Variabel Proses Terhadap Minat Beli Konsumen di Perumahan Kalimasada

Dari hasil pengujian hipotesis diketahui bahwa variabel proses tidak berpengaruh signifikan terhadap minat beli konsumen pada perumahan kalimasada. Dapat disimpulkan bahwa dalam sistem pembayaran maupun proses pengkreditan yang masih dianggap sukar ataupun sulit dalam melakukan akad jual beli rumah memberikan respon yang kurang baik bagi konsumen maupun user

\section{KESIMPULAN DAN SARAN}

Hasil penelitian dan pembahasan dapat disimpulkan bahwa bauran pemasaran yang terdiri dari produk, harga, tempat, orang, proses, promosi dan tampilan fisik mempunyai pengaruh yang signifikan terhadap minat beli rumah di kalimasada perumahan. Dapat disimpulkan bahwa semua variabel independen dalam penelitian ini secara bersamaan berpengaruh terhadap minat beli perumahan. Variabel promosi yang memiliki pengaruh paling dominan terhadap minat beli pada perumahan kalimasada dengan melihat nilai signifikansi terkecil, yaitu dengan nilai Sig. 0,006 (dengan nilai Signifikasi sebesar 0,05).

\section{DAFTAR PUSTAKA}

Alma. 2007. Manajemen Pemasaran dan Pemasaran Jasa. Edisi Revisi. Bandung.

Charles Lamb, W. et.al. 2001. Pemasaran. Edisi Pertama, Salemba Empat. Jakarta.

Kotler. 2007. Manajemen Pemasaran. Jilid I, PT. Indeks. Jakarta.

Lestari, Fuji Yudithya 2011. Bauran Pemasaran Terhadap Minat Beli Konsumen CV. Cari Rasa Bandung. 
Lupiyoadi. 2001. Manajemen Pemasaran Jasa Teori dan Praktek. Salemba Empat. Jakarta.

Saladin, Djaslim. 2006. Intisari Pemasaran dan UnsurUnsur Pemasaran. Linda Karya. Bandung.

Sarjono, Bambang. 2012. Analisis Pengaruh Strategi Bauran Pemasaran Terhadap Minat Beli Ulang Produk Baru.

Sugiyono. 2013. Statistik untuk Penelitian. Alfabeta. Bndung.

Tjiptono, Fandi. 2005. Strategi Pemasaran. Andi Offset. Yogyakarta.

Wally, A. A., Herminawati, H., \& Ruslan, M. (2020). Pengaruh Bauran Pemasaran Dan Kualitas Pelayanan Terhadap Komitmen Konsumen Melalui Keputusan Pembelian Roti Conses Makassar. Indonesian Journal of Business and Management, 2(1), 16-20. https://doi.org/10.35965/jbm.v2i1.172 